\title{
A Study on the Decentralized Planning and Socio-economic growth and Development with special reference to E-Governance initiatives in the state of Telangana
}

\author{
Lakshmi Prasad. Chinthalapalli \\ Addl. Director, TS Disaster Response and Fire \\ Services Department Fire Service and Disaster \\ Response, \& Research Scholar, Department of \\ Management, Rayalaseema University, \\ Kurnool, Andhra Pradesh, India
}

\author{
Dr. Y. V. Rao \\ Professor, Department of Management Studies, \\ VFSTR University, \\ Guntur, Andhra Pradesh, India
}

\begin{abstract}
The sustainable development of State requires infrastructure and good governance system i.e. Infrastructure, decentralized administration, digitalization, technology based E-governance; infrastructure finance will help the government of Telangana to attain the new heights of economic growth and development. The development process of Telangana is a better design through T-hub, Policy initiatives and peoples participation.
\end{abstract}

The overall development of State of Telangana is in right direction to bring the socio-economic development in the key areas of Agriculture, Industry and Service Sector. The state policy is for accelerating sustainable development and improving the strategic intervention in respect of e-governance, good governance, ICT education infrastructural development to achieve the improvement in employability and empowerment of youth and women. The government of Telangana is closely working with local, district and state level authorities to improve the social and economic infrastructure and industrial development through best industrial and agriculture policies.

1. The Socio Economic Outlook for Telangana has pegged the Gross State Domestic Product (GSDP) growth rate for current fiscal (2016-17) at 10.1\% at constant prices (2011-12) and at $13.7 \%$ at current prices.

2. As per the advanced estimates released by the Directorate of Economics and Statistics here on Monday, the volume of GSDP is estimated at Rs.
5.11 lakh crore at constant prices and Rs. 6.54 lakh crore at current prices. For the previous year it was estimated at Rs. 4.64 lakh crore and Rs. 5.76 lakh crore, respectively.

3. The document released as part of the budget presentation stated that prospects for Telangana's economy look much better and the growth rebound that happened during 2016-17 is expected to sustain in the coming years too as the benefits of ongoing programmes are visible.

4. The survey put the unemployment rate in the State at about $2.7 \%$ against the national average of $3.7 \%$.

The present research study had strategically analyzed the growth and development process of the government of Telangana in terms of sustainable development through decentralized planning, infrastructure and good governance practices. Infrastructure and good governance helps the government of Telangana to go ahead with a major expansion of investment, green infrastructure and efficient infrastructure will be essential for attaining the growth and sustainable goals.

The present infrastructure investment and financing model needs to be transformed fast if it is to enable the quality and quantity of growth the state economy needs. In this direction the present research is a strategic move towards suggesting best policy frame work to achieve government of Telangana's vision, mission and objectives in a sustainable model. 
The sustainable rural or urban development of the development of Infrastructure to utilize the resources state or country is only possible with the right and develop the e-governance best practices.

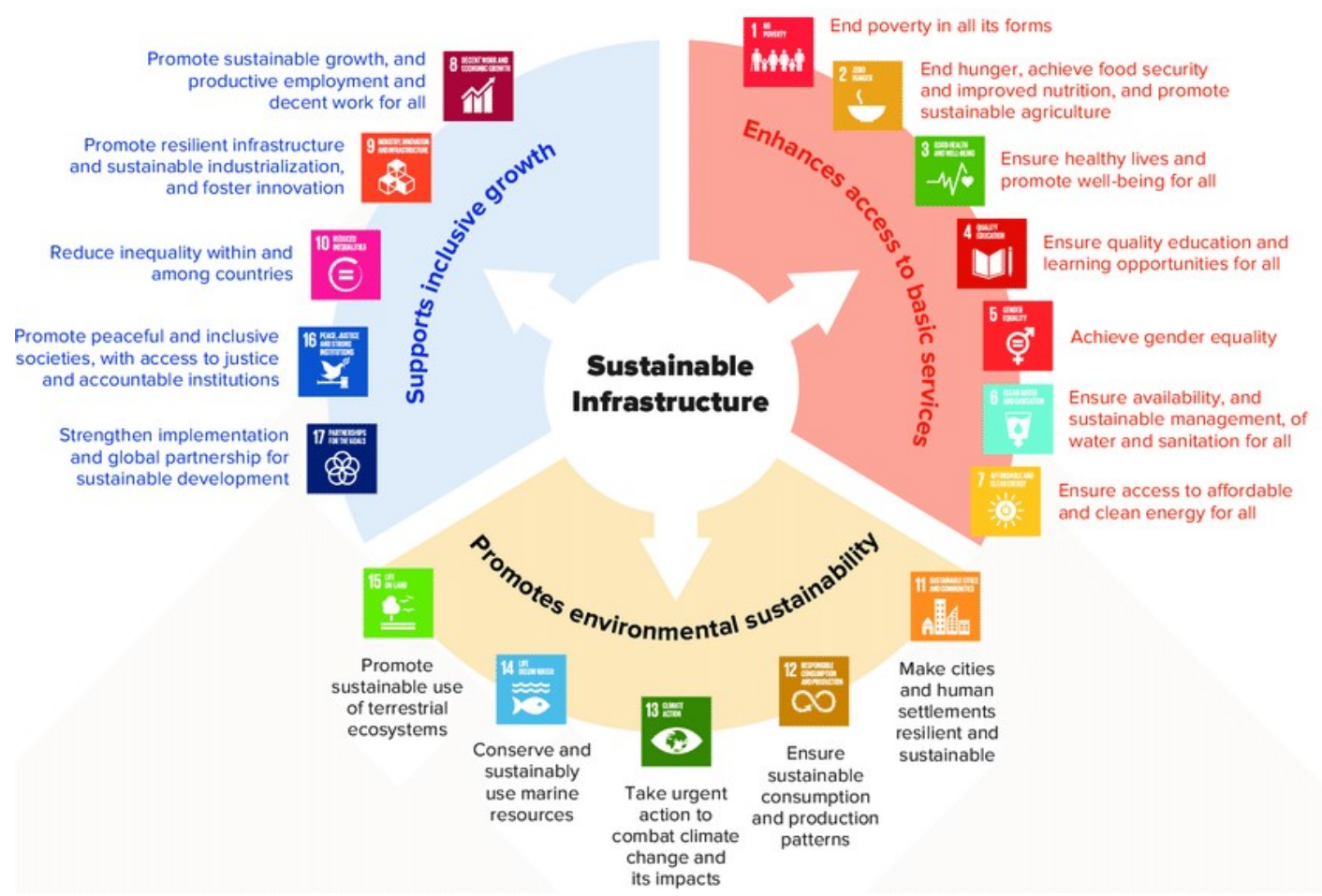

Figure 1.1: Sustainable Infrastructure

The Infrastructure Service in India: The infrastructure scenario in India being the seventh-largest country in the world has maintained an infrastructure management that has enabled India to reach new heights Developing Infrastructure includes economic (energy, power, telecom, transport, InfoTech, finance, etc) and social (education and health issues) infrastructure development.

\section{Objectives:}

1. To study the decentralised planning, infrastructure and good governance developments in India in general and Telangana in particular

2. To analyze the socio economic through decentralised planning in the State of Telangana

3. To study the government initiatives and policy measures towards development of infrastructure in India and Telangana

4. To analyze the contribution of e-Governance and smart city concept in the development process of Telangana

5. To suggest efficient and effective measures to develop infrastructure and best practices in the state of Telangana

\section{Methodology:}

The study was conducted with collecting primary and secondary data. Cluster sampling technique adopted by taking Rangareddy and Warangal districts in the state of Telangana. 500 sample respondents have been taken from the sample districts to obtain socioeconomic developments through decentralized planning and e-governance implementation.

The overall country need double-digit growth in manufacturing and services sectors in the next five years, and have to double farm output, if it was to meet the target achievements. The economy has grown at an average eight per cent in the past three years, and a 10 per cent annual GDP growth is difficult to achieve unless the country improves its infrastructure.

Infrastructure growth and development through decentralized planning is required in the following sectors

1. Transport \& Communication Infrastructure

2. Power Infrastructure

3. Financial Infrastructure

4. Social Infrastructure

5. Education Infrastructure

6. Health Infrastructure 
The Development of infrastructure and decentralized planning is one of the priorities for development of Indian economy towards social development. Good governance is required to a great extent to contribute soco-economic development through development of infrastructure in the areas of Agriculture, and Social \& Rural Infrastructure. The development of ICT and web based technology towards good governance practices to improve the decentralized planning system to develop smart cities and industrial development will contribute to the welfare of mankind.

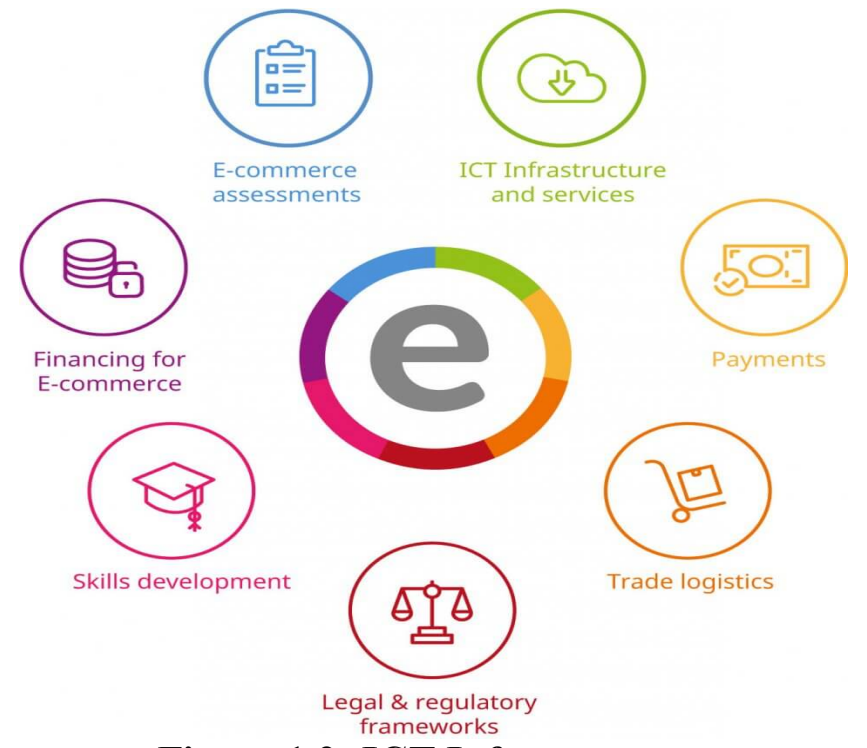

Figure 1.2: ICT Infrastructure
The present Government is facing various challenges such as best Governance, faster land, environmental and other policies, availability of long term funds, timely implementation of projects within estimated costs, and at the same time protecting interest of all stakeholders.

More number of Urban Infrastructure experts needed annually as said by the Expert Committee for estimating the investment requirements for Urban Infrastructure Roads, Power, Aviation, Seaports, Urban Infrastructure, Railways, Agriculture; Social \& Rural Infrastructure is struggling to keep pace with the expected results.

The development of Telangana state requires huge funds and technocrats with formal professional education for creating comprehensive \& multifaceted capabilities to improve the good governance system to improve the economic development and rural transformation process of Hyderabad capital into a world class capital by developing good infrastructure related to Roads, Power, Aviation, Urban Infrastructure, Railways, Agriculture, and Social \& Rural Infrastructure. Infrastructure was exclusively used to describe public assets that facilitate production, but not private assets of the same purpose which plays an important role in the development of an economy.

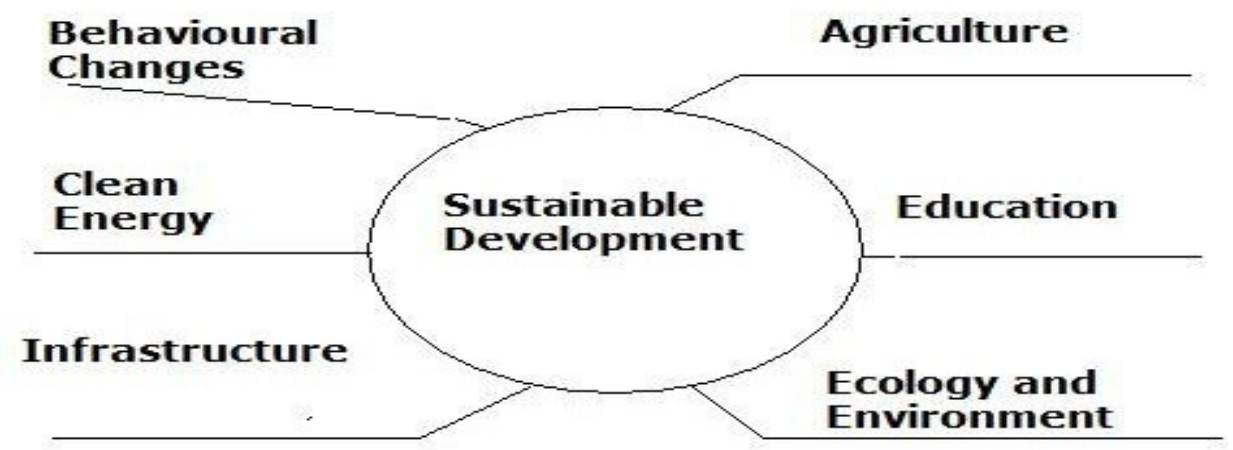

Figure 1.3: Sustainable Economic development

India is the fourth largest economy in the world. The development of infrastructure requires a further development in respect of Physical and social infrastructure which has a direct impact on the growth and overall development of an economy. The fast growth of the Indian economy in recent years has placed increasing stress on physical infrastructure, like electricity, railways, roads, ports, airports, irrigation, urban as well as rural water supply and sanitation. 
Infrastructure and decentralized planning for an economy:

Infrastructure and decentralized planning helps in the efficient utilization of country resources in respect of agriculture with the help of irrigation facilities, raw materials and industrial capacity of the country with the help of transport, communication, power facilities, and country's labour force with the help of education, training and health facilities.
1. Extension of market goes along with development of transport and communication facilities. If the monetary and financial institutions are properly developed in the country, the various sectors of economy can get finance easily and adequately

2. This increases the efficiency of labour by giving education training and health facilities, transport facilities which make it possible for the workers to go to long and distant places for work and this increases their mobility.

The direction of national development towards the middle path on foundations of the dynamic equilibrium of development and readiness to cope with potential changes.
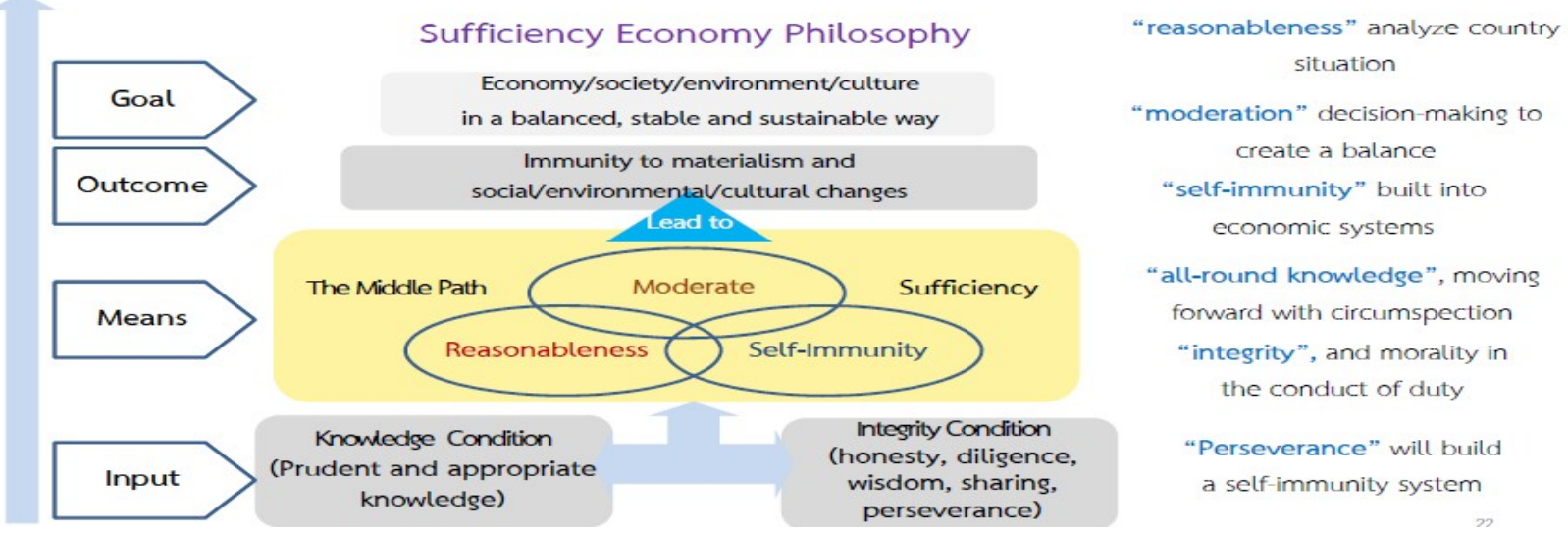

The development of the country largely depends on sound infrastructural facilities in respect of agriculture sector or the industrial sector. Without Infrastructure the output cannot be enhanced. If there is sufficient arrangement of irrigation in time it will boost up the agriculture production. Similarly industrial output also gets momentum with the help of power, transport and technical facilities. Infrastructure and decentralized planning of Economy For the sake of convenience we generally classify the infrastructures of an economy in two groups :-

\section{Infrastructure: Socio economic development}

Infrastructure is the basic requirement of economic development. It directly produce goods and services and facilitates production in primary, secondary and tertiary economic activities by creating positive external economies. The level of economic development in any country directly depends on the

development of infrastructure. The developed countries have made a tremendous growth of social and economic infrastructure and revolutionary progress in transport and communication sectors.
Infrastructure indicates that facilities and services which facilitate different economic activities and thereby help in economic development of the country in the areas Education, Health, Transport and, irrigation and power, Communication, banking and insurance and science and technology. Social overhead capital, produce, goods and services induce production in agriculture, industry and trade by generating external economies. For instance, an industry situated on or near the railway line or national highway will produce commodities at less cost.

The infrastructure can be divided into two categories: hard Infrastructure, soft Infrastructure.

Among the components that are classified under the infrastructure are the capital assets such as the public utilities, transport vehicles, telecommunication systems, roads, highways, railways, subways, traffic lights and street lights, dams, walls and culverts, drainage systems, the airports and bus terminals, and bridges, among others.

In respect of private infrastructure the land, the buildings and other improvements, the electric posts 
and the water systems, the warehouses and storage facilities, and the vehicles. Infrastructure is further classified into transportation, energy, communication, water management, measurement networks, and waste management.

\section{REFERENCES:}

1. Singh, S. P. (2000) „Gram Panchayats: Assessing Developmental Goals, Motivational Factors and Orientation: Evidence from a Field Studyee, Journal of Rural Development, 19 (3), pp. 371-97.

2. Smith,B.C.(1985) Decentralization: The Territorial Dimension of the State, London: George Allen \& Unwin.Stiglitz, J. (1994) Whither Socialism? MIT Press.

3. Tanzi, V. (1996) Fiscal Federalism and Decentralization: A Review ofSome Efficiency and Macroeconomic Aspects, Annual Bank Conference on Development Economics, The World Bank, Washington D.C., pp. 295-316.

4. Tharakan, P. K. M (1998) „Socio-religious reform movements, process of democratization and human development: The case of Kerala, SouthWest India ${ }^{e e}$, in: Rudebek, L., Törnquist, O. and Rojas, V. (eds) Democratisation in the Third World: Concrete cases in comparative and theoretical perspective, London: Macmillan and St. Martin ${ }^{\text {ee }}$ Press. 